\title{
Introduction to the Research Handbook on New Frontiers of Equality and Diversity at Work
}

\author{
Alain Klarsfeld, Lena Knappert, Angela Kornau, Eddy S. Ng and \\ Faith W. Ngunjiri
}

Managing diversity is now widely understood as both a societal and organizational concern around the world, beyond the US where the concept was originally conceived. Mirroring this diffusion to the political and corporate spheres, equality, diversity and inclusion ${ }^{1}$ (EDI) at work has become a fully-fledged scientific field of inquiry, with its own journals and dedicated book series with major academic publishers. This Handbook adds to this growing body of literature, but it also makes a contribution by filling an invisible gap which we will outline below. In spite of this diffusion and institutionalization, diversity management research is predominantly rooted in Anglo-Saxon countries and Europe, as has been evidenced in a recent systematic review of literature (Cachat-Rosset et al., 2017). As a result, EDI scholarship is mono-culturally infused and biased (e.g., Jonsen et al., 2011; Nishii \& Özbilgin, 2007).

EDI cannot be treated as universally understood concepts since contexts tend to shape how they are studied and implemented, as evidenced in country-specific and comparative perspectives on equal treatment and diversity (Klarsfeld, 2010; Syed \& Özbilgin, 2010; Klarsfeld et al., 2014; Klarsfeld et al., 2016a, 2016b). Such scholarship has brought nuance, but most of it focuses on Western countries, while voices from Latin America, Asia, and Africa are notably absent.

The silence may be explained through at least two complementary and intertwined interpretations. First, smaller and lesser-developed countries lack the necessary resources to initiate and sustain the needed research (UNESCO Institute for Statistics, 2019). This inevitably causes scholars from these countries to find better academic opportunities in the West, contributing to diversity management research there while depriving their countries of origin of much needed research (Docquier \& Rapoport, 2012). Second, diversity management research in smaller and lesser-developed countries is considered as less "sexy," publication-wise, and likely to be poorly received by Western academics (Özbilgin, 2004). Management scholars from smaller, lesser-researched countries are likely to pursue more prominent empirical fields (such as organizational behavior or human resource management) valued by mainstream scholars. Several contributors to this Handbook shared their experiences of being asked to justify the choice or rationale for studying a country or topic that has little relevance or importance to the West and reported experiences of rejection from reviewers and journal editors. In contrast, Western scholars benefit from the added advantage of similar academic preparation and research training as well as native fluency in English, which is dominant in academic work. As a result, their work is more aligned with reviewers and journal editors who are gatekeepers in the peer review process in academic research.

The invisibility of EDI research for small non-Western nations becomes more acute as they are viewed as marginal relative to the dominant West. We reflected on this, and in our initial planning for this project, we felt that even if we were unable to address the first issue, 


\section{Research handbook on new frontiers of equality and diversity at work}

we wanted to address the second. Therefore, we were intentional in inviting contributions from "under-researched countries" in our project, to give voice to EDI scholarship from many largely neglected geographical regions.

We first made an initial call for contributions for a special issue of Equality, Diversity and Inclusion: An International Journal. We attracted a total of 28 submissions from across five continents. After a standard peer-review process, we selected contributions from Bangladesh, Bosnia and Herzegovina, the Caribbean, Ethiopia, and (South) Korea (Klarsfeld et al., 2019). Based on this success, we expanded the project with another call for a special issue focused on India, which was met with the same success (Haq et al., 2020). This supported our intuition that, even though it was difficult to conceive this level of reception, we were able to reach out to non-universalistic and context-sensitive research in these under-researched countries. Since we received an overwhelming response (and far more proposals than can be accommodated with our two issues in a journal), we built on our momentum and extended our project to curate additional articles as chapters for this Handbook. Countries covered in this Handbook include Austria, Bangladesh, Bosnia and Herzegovina, Chile, India, Israel, Lebanon, Mexico, Morocco, Singapore, South Africa, and Turkey.

\section{COUNTRY-SPECIFIC PERSPECTIVES ON EQUALITY AND DIVERSITY}

Although discrimination and exclusion at work towards historically disadvantaged groups (such as women, racial minorities, or the LGBTQ+ community) are widespread globally, the focal target and magnitude of this marginalization are highly dependent on the context and history. Social categories and what are considered as minority groups vary by country (e.g., Kurds in Turkey, migrants and refugees in Europe, Indigenous peoples in Australia, Sunnis in Iraq, Shias in Pakistan, and Arabs in Israel). As a result, the treatment and protection of these marginalized groups also differ with respect to politically enforced exclusion, affirmative action and quotas, and aspirational goals.

While the 1990s witnessed an emerging interest in diversity management (DM) mainly focused on the US (Thomas, 1990; Cox, 1991; Cox \& Blake, 1991; Thomas \& Ely, 1996; Kelly \& Dobbin, 1998; Edelman et al., 2001), it also extended to the UK (Kandola \& Fullerton, 1994) and Canada (Agócs and Burr, 1996). Early milestones in explicitly context-sensitive writings followed somewhat later and focused on legal prescriptions such as Equal Employment Opportunity (EEO), Employment Equity (EE), or Affirmative Action (AA) (e.g., employment equity in Canada, and equal employment opportunities in the US and the UK). Country-by-country contributions (Agócs, 2002) and comparative research (Jain et al., 2003; Agócs \& Osborne, 2009) became more prominent subsequently, and documented a broad range of affirmative action policies. Some promote preferential treatment and quotas (e.g., in India and Malaysia), while others focus on process changes, numerical goals, and timetables for their implementation (e.g., in Canada, the USA, or Northern Ireland) (Jain et al., 2003).

Several meaningful differences and overlaps between DM and EEO/AA exist. First, DM promotes a business case and centers on voluntary initiatives, while EEO/AA programs center on legal prescriptions and reparation of (past) injustices. While earlier writings frequently differentiated DM versus EEO/AA along their business versus moral case (e.g., Thomas, 1990), 
some scholars took an integrative approach and proposed that equality and business objectives are complementary to each other (Cox \& Blake, 1991; Liff, 1999). Second, in contrast to EEO/ AA programs, DM is theoretically broader in scope as it also considers dominant groups and invites their participation (Thomas, 1990; Thomas \& Ely, 1996). Third, empirically, only few differences could be found between DM and EEO/AA programs (Kelly \& Dobbin, 1998). However, while the anti-discrimination rhetoric, legal threats, and a focus on gender and race were less appealing to managers, the introduction of DM provides similar initiatives and a novel and more compelling narrative to organizations and managers (Edelman et al., 2001).

Early DM literature was still very much US-centric. Outside of the US, comparative and cross-national research gained traction slowly. Agócs and Burr (1996) provided one of the earliest comparative and cross-national works in this area. They compared both DM with AA in the US, and with EE, a uniquely Canadian policy aimed at redressing past discrimination against four designated groups, i.e., visible minorities, women, persons with disabilities, and Aboriginal peoples. The authors found that AA and EE were both legal prescriptions. A central premise for both AA and EE is the achievement of proportionate representation by meeting numerical goals through a timetable. In contrast to AA and EE, which requires legal compliance, DM is a non-binding approach which focuses on organizational effectiveness and learning, access to markets, and gaining legitimacy among organizational members (Thomas and Ely, 1996). These approaches are very much a prototypical North American perspective, common to the US and Canada, to promote diversity and equity objectives (Agócs and Burr, 1996).

In the mid-2000s, EEO/AA and DM literatures were still overwhelmingly North American, and little was documented about how these concepts have diffused to other countries. Among the first European authors to address the gap, Boxenbaum (2006) explained how DM had been adapted to the Danish context, by taking into account the strong egalitarian and democratic culture of this country, which stands in stark contrast with that of the US. Boxenbaum used a case-study design. DM was also resisted and/or adapted in Sweden (Omanović, 2009). An entire special issue was dedicated to how DM had been adapted and translated to other, mostly European, contexts (Calas et al., 2009). The introduction of DM triggered resistance, or at the very least the necessity to reformulate diversity discourse within commonly agreed national frameworks.

Since then, national and/or country perspectives on diversity and equal treatment at work emerged as a topic and field of research in its own right (Haq, 2012; Klarsfeld, 2009; Klarsfeld, 2010; Klarsfeld et al., 2012; Klarsfeld et al., 2014; Klarsfeld et al., 2016b; Knappert et al., 2018; Tatli, 2011; Tatli et al., 2012). Special issues of the European Journal of Industrial Relations (Hyman et al., 2012), American Behavioral Scientist (Ng and Bloemraad, 2015), and Cross-cultural and Strategic Management (Klarsfeld et al., 2016a) were also devoted to national perspectives on EDI. These collections underscore how unique national approaches are required for EDI research. This can be illustrated with how different dimensions of diversity are relevant to different national contexts. For instance, sexual orientation and gender identity are addressed in some countries but not in others. Based on cross-national comparisons, equity legislations can be developed along a typology from positive discrimination (e.g., legally prescribed systematic preference for historically disadvantaged groups) to negative discrimination (e.g., legally sanctioned discrimination against disadvantaged groups).

This Handbook adds to a growing body of research that attends to a need to study DM beyond the US, and to question basic assumptions inherent in DM as theorized in the US and, 


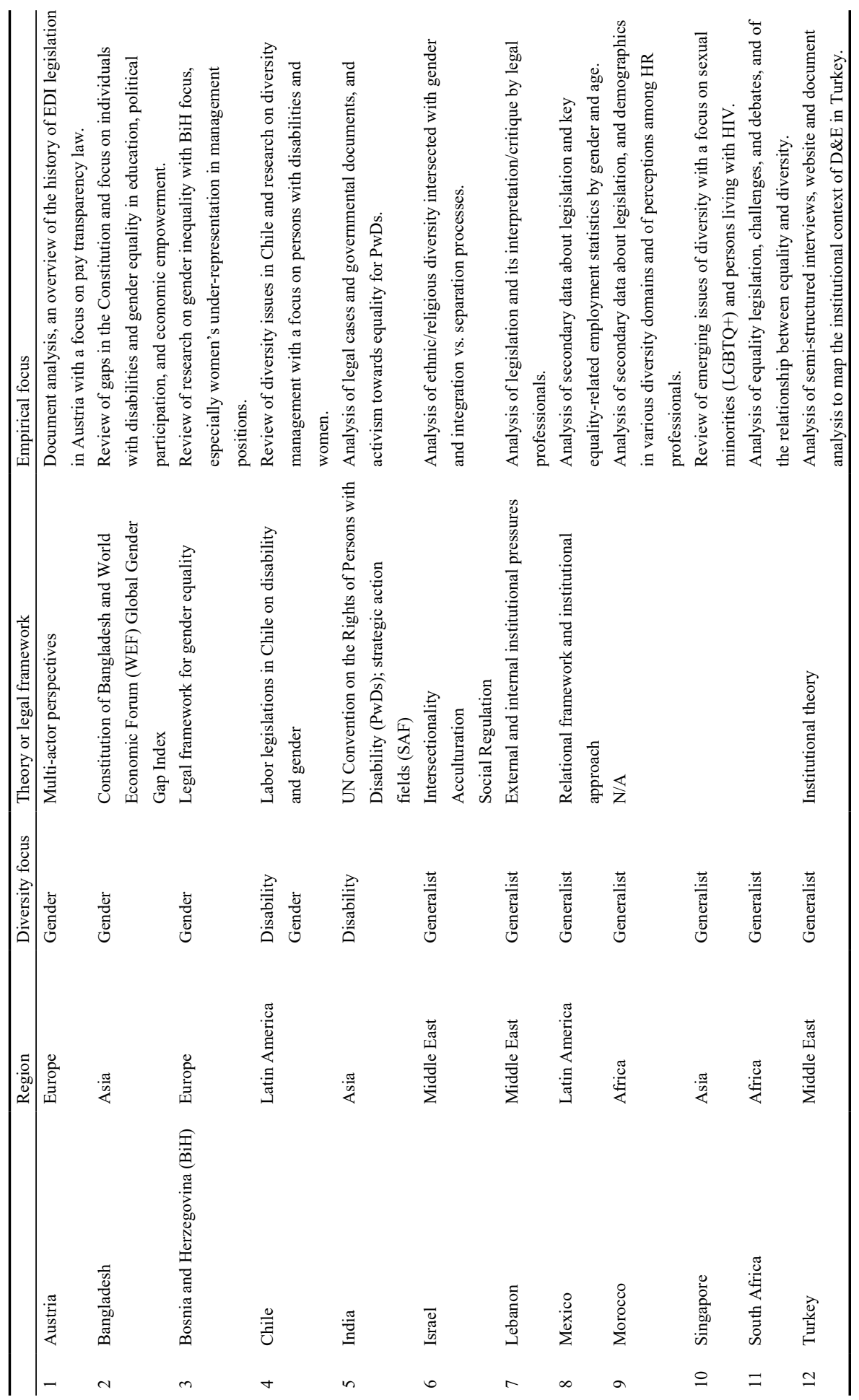


subsequently, in Europe. To date, many non-US countries have been researched and written, but an overwhelming majority are on Western European nations and/or well-developed democracies such as Australia, Canada, and New Zealand. Our understanding of how other countries experience EDI remains somewhat limited. How are their approaches different from those experienced in presently researched countries, or on the contrary, what commonalities can be found with them? These questions and many others are addressed in the contributions to this Handbook.

The contributions to this Handbook include specialist (i.e., focused on a specific demographic, generally gender) as well as generalist chapters, which is the category most represented. Most have an empirical focus, drawn from established secondary data sources, and a few are based on primary research data. Most also include a description of a legal framework within the appropriate national or supranational context. Some of the contributions draw from multidisciplinary theoretical frameworks including intersectionality (Crenshaw, 1991), acculturation (Berry, 2016), social regulation (Reynaud, 1997), the relational framework, and institutional theory. Table I.1 provides a summary view of the contributions.

\section{CONTRIBUTIONS}

Austria Isabella Scheibmayr and Astrid Reichel highlight an important case on a legal change aimed at increasing pay equality in Austria and analyze a unique legal regulation that was introduced in 2011 and requires employers to state minimum pay in job advertisements. The chapter draws on earlier multi-actor approaches (Özbilgin \& Tatli, 2011; Bourdieu, 1984) and considers various involved actors, their political interests, and historical context. The provided document analysis includes a two-step deductive content analysis (Mayring, 2002) of 272 draft legislations, parliamentary discussions, and commentaries as well as implementation guidelines by social partners and texts (such as professional journal articles) from the human resource professional community. In addition to providing a rich overview of the historical development of EDI legislation in Austria, the analysis shows how equality policies are introduced and how multiple actors shape their implementation. The chapter showcases the importance of considering the various actors (e.g., the legislative body, unions, equality experts, organizations), their roles (e.g., regulator, interest group, professional, implementer), and their interests involved in EDI policy formulation and implementation. As actors might negotiate or change the discursive framing of regulations in line with their interests, this can lead to consequences not anticipated by policy makers. For instance, equality policies framed as organizational practices have shifted from a transparency and fairness focus to a negotiation focus, emphasizing assumptions about women's deficiencies during salary negotiations. Austria is an interesting context for the study of EDI, because in spite of extensive legal policy, the country advances only slowly with respect to workplace equality, diversity, and inclusion. The chapter presents an explanation for this paradox that potentially applies to other contexts and may serve to inspire similar work sharing the same contextual backgrounds.

Bangladesh Samina Saifuddin, Harinder Chhina, and Laila Zaman provide the state of diversity and equality in Bangladesh through multiple lenses. Owing to a lack of empirical research, they first provide a critical review of the Bangladesh Constitution which guarantees equal rights for all citizens regardless of religion, race, caste, sex, or place of birth. While the Constitution is written in secular language, Islam is declared as the state religion. 
Unfortunately, this "creates an ambiguity that may prevent non-Muslims from equal opportunity and equal protection." Further, although the Constitution is meant to safeguard all citizens, regardless of social hierarchy or where one is in the caste system, those of a lower caste or having a lower socioeconomic status continue to experience discrimination, deprivation in relation to poverty and literacy, and high levels of violence. Thus, the constitutional rights are often viewed as illusionary. The Bangladeshi Constitution is also silent in the protection for Indigenous peoples (non-Bengali/Bangalee) from various tribal groups. Since it does not explicitly recognize the Indigenous population, it relieves the Bangladeshi government from its obligation to protect non-Bengalis. Finally, the Constitution guarantees equal rights, opportunity, and protection for women. However, Section 3(c) allows for reservations of employment due to the nature of the job, effectively allowing employers to discriminate against women in the hiring process. There are also parallel laws relating to personal laws addressing "marriage, divorce, inheritance, maintenance, and custody of children," which are religion-based, effectively rendering women unequal status. Their second review is focused on existing empirical research in Bangladesh. Their review found most work on diversity in Bangladesh is concentrated on ethnicity, people with disability, and women. Research that examines ethnicity drew attention to hardships faced by Indigenous people and ways to sustainably improve their livelihood and socioeconomic conditions. Research on disability indicated that disability in Bangladesh is a social taboo resulting in negative attitudes, exclusion, and the victimization of people with disabilities. The authors reference research by Miles et al. (2012) who suggest that it is necessary for government departments such as education and social welfare to partner with disability-focused NGOs to generate awareness. It is noteworthy that neither research on ethnic diversity nor people with disability were tied to employment equity. Their review also indicates that research on sex was given the most attention by management scholars, especially on education and employment. They found research to focus on the employment of professional women in relation to types of positions, women's access to opportunities in certain industries, male vs. female experiences in relation to work-life quality, and rural women's options in manners congruent to socially acceptable norms. In short, the authors conclude that women in Bangladesh do not enjoy equal status to men whether it's for professional women or the empowerment of rural women.

Bosnia and Herzegovina Almina Bešić, Zijada Rahimić, Christian Hirt, and Renate Ortlieb examine gender inequality and focus on the under-representation of women in management positions in the context of a transition economy in South-Eastern Europe. Bosnia and Herzegovina is located in the south-west of the Balkan Peninsula and gained independence after secession from Yugoslavia in 1992. Being in a pre-accession process toward a candidate status for joining the EU, Bosnia and Herzegovina has developed a comprehensive regulative framework to combat discrimination against women, yet implementation remains largely ineffective because violations are not sanctioned. While the share of women in managerial positions in Bosnia and Herzegovina is higher than for many Organisation for Economic Co-operation and Development countries due to its socialist heritage, women remain in lower or less prestigious management positions and are underpaid compared to their male counterparts. Reasons for this situation include stereotypes in a "male domain," the gendered division of labor in a patriarchal society, the double burden of managing career and family, and a lack of self-confidence due to early socialization into stereotypical gender roles. Regarding the latter point, the authors "zoom in" and use illustrative data from a survey conducted in small and medium-sized enterprises to show that such patterns seem to change slowly given that 
young female respondents reported high self-confidence and ambition to take on managerial roles. To understand how the specific context of Bosnia and Herzegovina impedes women's advancement to decision-making positions, five major reasons are identified: (1) women are sidelined in management positions, (2) regulations and laws are not fully implemented, (3) there is a patriarchal view of women's role in business and society, (4) there is a depreciative self-perception of women in management positions, and (5) a low awareness of gender equality across society. Several practical implications are offered including mentoring programs and other supportive structures for women. However, only joint efforts by various actors, especially the government and business organizations, may tackle these complex problems.

Chile Francisca Álvarez-Figueroa, Juan Pablo Queupil, and Daniel A. Díaz examine Chile's diversity on issues related to diversity changes, diversity-based labor legislation, research findings on diversity management, and the reshaping of the workforce in light of growing diversity. The key demographic concerns for Chile are immigrants, an aging population, women, and Indigenous groups. Chile has more recently experienced an influx of immigrants, increasingly from neighboring countries and over a short span of time. An aging Chilean population, together with longer life expectancy and a birth rate that is not increasing also adds to a growing concern and challenges for employers having to manage a workforce with a broader age range. Issues of gender are also a concern, with women reporting a lower rate of employment than men, and correspondingly a higher rate of unemployment. Finally, the Indigenous peoples of Chile who traditionally worked in agriculture and work associated with lower socioeconomic status have endured discriminatory and exclusionary processes in Chile. The authors find that the confluence of gender, an aging population, Indigenous concerns, and an influx of immigrants have made diversity an issue, a topic, a problem, and a challenge. Although Chile is aligned with international conventions, efforts related to the protection of disability status, gender, immigrant workers, and other worker characteristics regulated by labor norms are disaggregated in different legislative bodies. Thus, although Chile is a signatory of multiple international treaties and conventions, little of that is reflected in national legislations. Only women and people with disabilities have some degree of protection; however, the protection is uneven. The law on arbitrary discrimination is broad and does not yield meaningful support. This situation reveals that inclusion and equity of minorities in the workplace is scarcely regulated by law in Chile. The authors present analyses of diversity management research conducted in Chile. In a review of 25 journals over a 25 -year period, the authors report an upward trend in the number of publications, particularly over the last eight years. The trend reflects a growing interest in research related to diversity, with $60 \%$ of the articles published in the last five years. Slightly more than half $(52 \%)$ of the journals are published in Spanish, and the remainder (48\%) are published in English. The authors observe that there is no dominant journal devoted to issues of diversity, most (22 out of 24) have only published a single article. Most of the studies were qualitative in nature, with only four quantitative studies, and one literature review. One article explicitly covered diversity management. The growing diversity of the Chilean population is reshaping the characteristics of the Chilean workforce, making diversity an immediate concern for policy makers. The Chilean Constitution only protects the rights of its citizens, leaving those without status with little protection. The authors conclude that Chile is very much discovering its diversity and is at the first stage of diversity awareness. Public and private institutions are overwhelmed and are seeking assistance in dealing with issues of diversity. While there are international legislative 
frameworks, there is a long road ahead for Chile to translate them into local legislation that can adequately inform decisions and shape organizations and institutions.

India Amit Jain and Shreyashi Chakraborty examine the impact of legislation on employment opportunities for people with disabilities in India. As the world's second most-populated country, India currently counts more than 26 million people with disabilities (NSSO, 2018), which makes this present chapter particularly salient. Further, studying opportunities for people with disabilities in the Indian context is critical given the significant changes since India's independence (1947) from the British Empire and adoption of the Indian Constitution (1950) that prohibits discrimination and ensures equal opportunities for people with disabilities in public employment. Drawing on a rich body of data (including legislations, court proceedings, government reports, orders, and office memorandums), the chapter follows a doctrinal or theoretical legal research methodology (Dobinson \& Johns, 2017) to flesh out what the law means in this specific area. Jain and Chakraborty apply the theory of strategic action fields (SAF) (Fligstein \& McAdam, 2011), which describes a meso-level social order in which individual or collective actors interact, while being aware of each other, and the purpose and the power relations within the field. Building on SAF theory's proposition that the conditions of stability and change and the combination of actors would change over time, four historical phases of people with disabilities' employment can be identified. For each phase, the Indian disability employment SAF is charted, presenting the key events, discussing introduced laws, and showing how different actors work towards increased employment opportunities for people with disabilities through legal activism. In conclusion, despite some setbacks, people with disabilities' employment opportunities are continuously improving in India, due to actors' efforts and activism in the Indian disability employment SAF.

Israel Alain Klarsfeld and Avi Kay address a visibility paradox. As Israel regularly stands out in the media, it is not - at first glance - a marginal country. Indeed, the congregation of journalists in Jerusalem is the highest in the world per capita. However, while there is ample media coverage regarding military and political events unfolding in the Middle East, very little attention is directed towards the inner workings of Israeli society, which remain largely invisible. The purpose of their chapter is to address this lacuna by presenting an overview of how issues related to diversity play out in Israeli society. Specifically, the chapter addresses diversity in Israeli society via a discussion of the reality and relations (1) between the Jewish majority and diverse groups of Israeli Arabs, (2) between Jews from a European background ("Ashkenazim") and those whose families hail from Muslim countries ("Mizrachim"), (3) between Ultra-Orthodox ("Haredi") Jews and other Jews, as well as (4) issues of gender and sexual identity. Berry's acculturation theory (Berry, 2016), Reynaud's social regulation theory (Reynaud, 1997), and Crenshaw's intersectionality theory (Crenshaw, 1991) are used to unpack Israeli reality - a fragmented, but vibrant society where voluntary organizations pursue all kinds of sometimes-rival change agendas. Israeli society experiences the paradoxes of many Western societies with high economic performance, associated with growing economic inequalities, and growing identity politics giving more voice and power to autonomous regulation (in Reynaud's terms) pushing towards separation and segregation (in Berry's terms). Where objective conditions for successful integration seem to be present, the strong economic inequalities between entire segments of the population are being politically exploited to reinforce identity politics that tend to maintain segregation and separation in spite of pushes towards more integration such as growing education attainment in lower-status segments. The only hope for the future is that autonomous regulation activism conducted by civil society 
succeeds in creating local and national successful integration of the lower-status segments of Israeli society, and a reinforcement of an overarching Israeli identity as opposed to intersecting ethnic/religious identities. Furthermore, gender inequality itself cannot be understood (and gender equality achieved) and acted upon without using an intersectionality lens that allows an unpacking of varied patterns of gender inequalities and segregation, each specific to religious and ethnic groups.

Lebanon Charlotte M. Karam's chapter is a case study that aims to explore the notion of diversity in Lebanon. She provides a brief analytic framework that attempts to organize the analysis along the external and internal considerations that, together, shape the way in which diversity is conceptualized locally within national legislation, and how this conceptualization plays out in terms of protecting or failing to defend various persons at work in the country. Based on a series of in-depth interviews with 33 legal experts, the chapter suggests that the conceptualization of diversity is grounded in and shaped by considerations linked to geopolitical history, international benchmarks, and standards, as well as by local legal dynamics and practical experiences. Most salient in the findings is the influence of sectarian-based identities and divisions that play a significant role in shaping how diversity is understood, protected, and managed in the country. Lebanon is an interesting case in point as it is somehow going against the mainstream, where many countries structured around the left/right political divide that reflected class struggles are moving towards identity-based (such as religious/ethnic/ color) politics. Lebanon seems to have exhausted the identity-based political model and the population is calling for new models. Taken together, the author attempts to unpack this call, and to explore local notions of diversity as a key first step towards more diverse and inclusive workplaces. Her analysis suggests that indeed, as the call for chapters noted, "managing and developing diversity is on the political and business agendas," but beyond this she also asserts that managing diversity is an intimate part of the politics itself, carrying the weight of historical bloodshed as well as the dire need for future reconciliations beyond a tie to identity politics. Karam takes the work of Al Ariss (2010) and Al Ariss and Sidani (2016) one step further by providing rare insights from insiders of the Lebanese judiciary system.

Mexico Isis Gutiérrez-Martínez and Miguel R. Olivas-Luján investigate the evolution and effectiveness of employment legislation in Mexico, with a specific focus on age and gender diversity. The authors have chosen this focus not only because of its relevance for a large proportion of the population, but also because Mexico has implemented various anti-discrimination laws aiming to protect these groups, including, e.g., the General Law for Equality between Women and Men (2006) and the Law for the Rights of Elderly People (2002). They seek to explore the extent to which such legislative instruments have been effective. Building on the relational framework by Syed and Özbilgin (2009) and institutional theory (Scott, 1995) with an emphasis on regulative, normative, and cognitive institutions, the chapter accounts for the influence of macro-level factors in shaping the actual implementation of gender and age equality in employment. Empirically, secondary data from official sources (such as government publications and the Mexican census database INEGI) focusing on the period between 2005-2018 is analyzed to explore the link between legislative instruments and statistical labor market indicators, such as economic participation and wage by gender and age. Despite important amendments to the law, Mexico is still far from equitable in important labor market indicators and, hence, progress remains marginal - one exception being the decreasing gender wage gap for top and middle management positions (a reduction of $16.8 \%$ points between 2005-2018). The lack of effectiveness of regulative instruments can be attributed to slow 
adoption of the law, a lack of efficiency in the application of enforcement mechanisms, and a lack of fiscal incentives. Furthermore, normative and cultural-cognitive institutions, such as machismo, are particularly powerful in undermining equality and diversity efforts in Mexico. This indicates that progressive legislation alone is insufficient to create significant coercive pressure to improve equality and diversity, a finding that resonates with reports from other Latin American countries.

Morocco Doha Sahraoui Bentaleb and Asma Ait Bounssiyal provide an overview of diversity challenges in Morocco through a review of the literature, national statistics, as well as a qualitative inquiry into human resource managers' perceptions about what is at stake for them when it comes to diversity. The chapter covers four dimensions of diversity including gender, age, ethnicity, and ability. The various statistical and historical data show increasing demographic heterogeneity, which evolves with new immigration trends as well as urbanization. These new trends challenge the various standardized national models previously taken for granted. The diversification of the population is therefore reflected in companies, as they now have to manage employees who are different from the historically dominant, ethnically undifferentiated middle-aged men. The results of the authors' literature review, as well as their field exploration, demonstrate different levels of consciousness based on the dimension of diversity raised. Gender is the diversity dimension of which interviewees are most aware. Both their responses and national statistical data reveal an interest in the issue, as well as a predisposition to deploy efforts to integrate women into the labor market. Sadly, even if Moroccan society embraces women's education and work, it continues to resist the full empowerment of women. For persons with disabilities, companies perceive a social imperative to integrate them. However, this imperative is a matter of compliance with a legal requirement rather than viewing persons with disabilities as an asset to be integrated. For inter-generational management, both the aging population and the integration of a new generation within companies pose new challenges to human resource managers. Organizations seek to take advantage of older workers' experience and also to inject new blood into the workforce, but this coexistence does not always occur in a de facto manner within companies. The form of diversity that is most often overlooked is ethnicity. Interviewees recognize it and name it but seem to want to ignore it.

Singapore Angeline Cuifang Lim, Jefferson Karthikeyan Rajah, Julian Wei Meng Sng, and Yee Han Kuan offer a review of Singapore's population and a primer on its approach to diversity management in light of Singapore's culture. Singapore has long-standing diversity management policies. Its pre-independence racial riots serve as a reminder of the need to remain on a path of equality and harmony. Much legislation has been implemented in the past 50 years to ensure Singapore's progress in this endeavor. Over the past ten years, there have been significant shifts in diversity management. One shift is the national focus from "equality and harmony" to "diversity and social inclusion," which has been spurred by changes in Singapore's workforce. Another shift has been from mainly transferring government agency-based diversity management efforts to private businesses and organizations taking charge in advancing inclusion and diversity. Finally, there is a shift in broadening inclusion of different diversity types. The authors elected to focus on the last two, i.e., the role of government agency (TAFEP) and emerging diversity pertaining to LGBTQ and persons living with HIV (PLHIV). The Singapore government established the Tripartite Alliance for Fair and Progressive Employment Practices (TAFEP), an agency committed to legislation to address non-discriminatory employment practices that could be implemented in workplaces. 
It is a quasi-governmental agency that mainly plays an advisory and supportive role. TAFEP has a four-stage plan (Starting Out, Being Fair, Being Progressive, and Being Exemplary) for workplaces to follow to promote diversity and inclusion. Each stage is meant to build on the previous one, starting with compliance with Singapore's existing labor laws to recognizing employers who have fully followed the guidelines. These latter organizations become eligible to receive two awards for their commitment to progressive practices. TAFEP as an agency is primarily non-legislative. However, it has recently been given some legislative backing. This means that organizations which are not in compliance with TAFEP guidelines can be penalized. The authors also discuss two paramount diversity issues in Singapore: the LGBTQ population and its fight for legitimacy within the Singapore government, and the unintentional progress of persons living with HIV (PLHIV) in Singapore. Singapore lags others globally in relation to policies on diversity and inclusion for the LGBTQ community. Non-inclusion is rooted in the still-existing penal code in which consensual sexual activity between men is criminalized, and in Singapore's conservative negative attitude towards homosexuality. The government has chosen to not strike the criminalization legislation from the laws, but it no longer prosecutes based on this law. As a result, LGBTQ people still battle against discriminatory behavior in both society and the workplace. Likewise, HIV has a deep-rooted stigma and fear attached to it in Singapore. PLHIV fear discrimination, particularly in the workplace, and rightly so - data leaked in 2019 which contained personal information from the HIV registry created additional stress and worry for those in the PLHIV community.

South Africa Nasima Carrim, Caren Brenda Scheepers, and Leon Moolman describe employment equity legislation within the South African context. They began their chapter by historicizing the unique case of Apartheid South Africa where the 1926 Job Preservation Act safeguarded South African White people's jobs and interests over those of Indigenous African, Indian, and mixed-race workers. They observe that the lack of legislation to protect Black people, women, and disabled people from discriminatory work practices - such as unequal salaries for equal work, and the aspirations and opportunities of these employees - were limited because employers could dismiss them at the slightest provocation (Carrim, 2019; Lee, 2016; Naidoo, 2018). The first democratic election of 1994 ended 46 years of inequality and racial discrimination rooted in practices, social structures, and attitudes that dated back to the beginning of the nineteenth century (Allanson et al., 2002). As a result of the political transformation, demographically diverse populations entered the South African corporate sector. After 1994, many labor laws, as well as the Constitution of South Africa (South Africa, 1996b), were reformulated to redress the discrimination experienced by previously disadvantaged individuals (Seekings, 2008). The Employment Equity Act No. 55 of 1998 (South Africa, 1998a) (hereafter EEA) was promulgated to provide previously disadvantaged groups the opportunity to enter and progress within corporate South Africa (Booysen \& Nkomo, 2010). The authors focus their chapter on exploring the EEA, academic contributions relating to the EEA and the challenges South African organizations face in implementing employment equity and affirmative action. They conclude by focusing on the relationship between diversity management and employment equity in the South African context.

Turkey Duygu Acar Erdur analyzes the influence of country-specific institutions on EDI. Building on institutional theory and on Kostova's (1999) Country Institutional Profile in particular, the chapter develops a country-institutional profile of EDI by defining the regulative (e.g., EDI laws and regulations, governmental policies), normative (e.g., the influence of non-governmental organizations on the D\&E debate), and cognitive (e.g., representation 
of EDI in mainstream media) elements of the national context that shape EDI in Turkey. Providing an encompassing picture of the Turkish institutional context on EDI at work, relevant parts of the country's constitution and labor law, websites by NGOs, annual and/ or sustainability reports by three family business groups, six semi-structured interviews with diversity association representatives and MNC HR managers, as well as media outlets are analyzed. In an increasingly politicized Turkish institutional context, gender diversity is particularly prominent, while other diversity dimensions (such as LGBT+ or ethnic diversity) are being marginalized across all three institutional pillars. In particular, the influence of the country's current political climate on EDI - which is fueled by the government's conservative and more and more authoritarian policies - is demonstrated. Further, some diversity dimensions (e.g., ethnicity, sexual orientation) are particularly silenced as part of the larger political program that runs on a strict "us" versus "them" distinction. The chapter's findings therefore may also be relevant for other contexts where authoritarian and nationalist tones are on the uprise and may hopefully inspire similar studies in the future.

\section{CONCLUSION}

This Handbook, based on context-specific equality and diversity research, covers a wide range of countries from less visible regions, including countries from the Middle East and Asia. All of the contributions provide insightful understandings of the national legislative frameworks and their functioning as well as context-specific critiques of the state of equality and diversity in the respective countries. What becomes evident when reading the chapters is that the ways in which diversity and diversity initiatives are understood and enacted are starkly different and diverse. For instance, authors emphasize the role of geopolitical forces and postcolonialism (i.e., Lebanon), social dialogue of multiple actors (i.e., Austria), historically ingrained stereotypes (i.e., Bosnia and Herzegovina, Mexico), intersectionality (i.e., Israel), or political climate (i.e., Turkey) in shaping the discourses, meanings, and outcomes of equality and diversity regulations and initiatives. These macro-level factors allow for a locally grounded analysis, which also shines a spotlight on the complex interplay of identity, politics, and history, all of which are key to understanding diversity issues.

As editors and researchers from "the West" and often with intersectional identities from other origins, we felt particularly privileged to be involved in this project. We have been fortunate to have had this opportunity to engage in a mutual learning process, whereby we could reflect upon and question our own taken-for-granted assumptions and at the same time learn about how inequality is fought in various countries, each with its unique struggles and challenges that are faced by local actors.

\section{NOTE}

1. For the purpose of this Handbook, we will use equality, diversity, and inclusion (EDI) as a shorthand to denote all the allied concepts associated with diversity, equity, equality, and inclusion. 


\section{REFERENCES}

Agócs, C. (ed.) (2002). Workplace Equality: International Perspectives on Legislation, Policy and Practice, The Hague, the Netherlands: Kluwer Law International, p. 290.

Agócs, C. \& Burr, C. (1996). Employment equity, affirmative action and managing diversity: assessing the differences, International Journal of Manpower, 17(4/5), 30-45.

Agócs, C., \& Osborne, B. (2009). Equity policies in Canada and Northern Ireland: policy learning in two directions? Canadian Public Policy, 35(2), 237-262.

Al Ariss, A. (2010). Religious diversity in Lebanon: lessons from a small country to the global world, in J. Syed \& M. F. Özbilgin (Eds.), Managing Cultural Diversity in Asia: A Research Companion (pp. 56-72), Cheltenham, UK: Edward Elgar Publishing.

Al Ariss, A. \& Sidani, Y. M. (2016). Understanding religious diversity: implications from Lebanon and France, Cross Cultural \& Strategic Management, 23(3), 467-480.

Allanson, P., Atkins, J. P., \& Hinks, T. (2002). No end to the racial wage hierarchy in South Africa? Review of Development Economics, 6(3), 442-459.

Berry, J. (2016). Diversity and equity, Cross Cultural and Strategic Management, 23(3), 413-430.

Booysen, L., \& Nkomo, S. (2010). Employment equity and diversity management in South Africa, in A. Klarsfeld (Ed.), International Handbook on Diversity Management at Work (pp. 218-244), Cheltenham, UK: Edward Elgar Publishing. https://doi.org/10.4337/9780857939319.00018

Bourdieu, P. (1984). Distinction: A Social Critique of the Judgement of Taste, trans R. Nice. Routledge classics. Routledge, Taylor \& Francis Group.

Boxenbaum, E. (2006). Lost in translation, the making of Danish diversity management, American Behavioral Scientist, 49(7), 939-948.

Cachat-Rosset, G., Carillo, K., \& Klarsfeld, A. (2017). Reconstructing the concept of diversity climate a critical review of its definition, dimensions, and operationalization, European Management Review. First published September 2006. https://oi.org/10.1111/emre.12133

Calas, M. B., Holgersson, C., \& Smircich, L. (2009). "Diversity management"? Translation? Travel? Scandinavian Journal of Management, 25(4), 349-351.

Carrim, N. M. H. (2019). The in-betweeners: racioethnic and masculine identity work of Indian male managers in the South African private sector, Journal of Men's Studies, 27(1), 3-23. https://doi.org/ $10.1177 / 1060826518778239$

Cox Jr, T. (1991). The multicultural organization, Academy of Management Perspectives, 5(2), 34-47.

Cox, T. H., Jr., \& Blake, S. (1991). Managing cultural diversity: implications for organizational competitiveness, Academy of Management Executive, 5(3), 45-56.

Crenshaw, K. (1991). Mapping the margins: intersectionality, identity politics, and violence against women of color, Stanford Law Review, 43(6), 1241-1299.

Dobinson, I., \& Johns, F. (2017). Qualitative legal research, in M. McConville \& W. H. Chui (Eds.), Research Methods for Law (p. 316), Edinburgh: Edinburgh University Press.

Docquier, F., \& Rapoport, H. (2012). Globalization, brain drain, and development, Journal of Economic Literature, 50(3), 681-730.

Edelman, L. B., Fuller, S. R., \& Mara-Drita, I. (2001). Diversity rhetoric and the managerialization of law, American Journal of Sociology, 106(6), 1589-1641.

Fligstein, N., \& McAdam, D. (2011). Toward a general theory of strategic action fields. Sociological Theory, 29(1), 1-26. https://doi.org/10.1111/j.1467-9558.2010.01385.x

Haq, R. (2012). The managing diversity mindset in public versus private organizations in India, The International Journal of Human Resource Management, 23(5), 892-914.

Haq, R., Klarsfeld, A., Kornau, A., \& Ngunjiri, F. W. (2020). Diversity in India: addressing caste, disability and gender, Equality, Diversity and Inclusion: An International Journal, 39(6), 585-596.

Hyman, R., Klarsfeld, A., Ng, E., \& Haq, R. (2012). Introduction: social regulation of diversity and equality, European Journal of Industrial Relations, 18(4), December, 279-292.

Jain, H. C., Sloane, P. J., \& Horwitz, F. (Eds.) (2003). Employment Equity and Affirmative Action: An International Comparison, New York: M. E. Sharpe.

Jonsen, K., Maznewski, M. L., \& Schneider, S. C. (2011). Diversity and its not so diverse literature: an international perspective, International Journal of Cross Cultural Management, 11(1), 35-62. 


\section{Research handbook on new frontiers of equality and diversity at work}

Kandola, R. S., \& Fullerton, J. (1994). Managing the Mosaic: Diversity in Action. Institute of Personnel and Development.

Kelly, E., \& Dobbin, F. (1998). How affirmative action became diversity management: employer response to anti-discrimination law, 1961-1996, American Behavioral Scientist, 41(7), 960-984.

Klarsfeld, A. (2009). The diffusion of diversity management: the case of France, Scandinavian Journal of Management, 25(4), 363-373.

Klarsfeld, A. (Ed.) (2010). Country Perspectives on Diversity and Equal Treatment at Work, Cheltenham: Elgar.

Klarsfeld, A., Combs, G. M., Susaeta, L., \& Belizón, M. (2012). International perspectives on diversity and equal treatment policies and practices, in C. Brewster \& W. Mayrhofer (Eds.), Handbook of Research on Comparative Human Resource Management (pp. 393-415), Cheltenham: Elgar.

Klarsfeld, A., Booysen, L. A. E., Ng, E., Roper, I., \& Tatli, A. (Eds.) (2014). Country Perspectives on Diversity and Equal Treatment at Work, 2nd edn., Cheltenham: Elgar.

Klarsfeld, A., Ng, E. S., Booysen, L. A. E., Castro-Christiansen, L., \& Kuvaas, B. (2016a). Comparative equality and diversity: main findings and research gaps, Cross-cultural and Strategic Management, 23(3), 1-37.

Klarsfeld, A., Ng, E. S., Booysen, L. A. E., Castro-Christiansen, L., \& Kuvaas, B. (2016b). Research Handbook of International and Comparative Perspective on Diversity Management, Cheltenham: Elgar.

Klarsfeld, A., Knappert, L., Kornau, A., Ngunjiri, F. W., \& Sieben, B. (2019). Diversity in under-researched countries: new empirical fields challenging old theories? Equality, Diversity and Inclusion, 38(7), 694-704.

Knappert, L., Kornau, A., \& Figengül, M. (2018). Refugees' exclusion at work and the intersection with gender: insights from the Turkish-Syrian border, Journal of Vocational Behavior, 105, 62-82.

Kostova, T. (1999). Transnational transfer of strategic organizational practices: a contextual \$perspective, Academy of Management Review, 24(2), 308-324.

Lee, H. A. (2016). Affirmative action regime formation in Malaysia and South Africa, Journal of Asian and African Studies, 51(5), 511-527.

Liff, S. (1999). Diversity and equal opportunities: room for a constructive compromise? Human Resource Management Journal, 9(1), 65-75.

Mayring, P. (2002). Einführung in die qualitative Sozialforschung: Eine Anleitung zum qualitativen Denken, 5th edn., Beltz.

Miles, S., Fefoame, G. O., Mulligan, D., \& Haque, Z. (2012). Education for diversity: the role of networking in resisting disabled people's marginalization in Bangladesh, Compare: A Journal of Comparative and International Education, 42(2), 283-302.

Naidoo, V. (2018). Has affirmative action reached South African women?, in L. E. Lucas (Ed.), Unpacking Globalization. Markets, Gender and Work (pp. 177-190), Plymouth, UK: Lexington Publishers.

Ng, E. S., \& Bloemraad, I. (2015). A SWOT analysis of multiculturalism in Canada, Europe, Mauritius, and South Korea. American Behavioral Scientist, 59(6), 619-636.

Nishii, L. H., \& Özbilgin, M. F. (2007). Global diversity management: towards a conceptual framework, The International Journal of Human Resource Management, 18(11), 1883-1894.

NSSO (2018). Persons with Disabilities in India: NSS 76th round (p. 209). http://mospi.nic.in/sites/ default/files/publication_reports/Report_583_Final_0.pdf

Omanović, V. (2009). Diversity and its management as a dialectical process: encountering Sweden and the US, Scandinavian Journal of Management, 25(4), 352-362.

Özbilgin, M. (2004). "International" human resource management: academic parochialism in editorial boards of the "top" 22 journals on international human resource management, Personnel Review, 33(2), 205-221.

Özbilgin, M., \& Tatli, A. (2011). Mapping out the field of equality and diversity: rise of individualism and voluntarism, Human Relations, 64(9), 1229-1253. https://doi.org/10.1177/0018726711413620

Reynaud, J. D. (1997). Les règles du jeu, 2ème edition, Paris: Armand Colin.

Scott, W. R. (1995). Institutions and organizations, Sage.

Seekings, J. (2008). The continuing salience of race: discrimination and diversity in South Africa, Journal of Contemporary African Studies, 26(1), 1-25. 
South Africa (1996b). Constitution of the Republic of South Africa, No 108 of 1996. Retrieved from www.info.gov.za/documents/constitution/1996/a108-96.pdf

South Africa (1998a). Employment Equity Act, No 55 of 1998. Available from http://www.hpcsa.co.za

Syed, J. \& Özbilgin, M. (2009). A relational framework for international transfer of diversity management practices, The International Journal of Human Resource Management, 20(12), 2435-2453.

Syed, J. \& Özbilgin, M. F. (Eds.) (2010). Managing Cultural Diversity in Asia: A Research Companion, Cheltenham: Elgar.

Tatli, A. (2011). A multi-layered exploration of the diversity management field: diversity discourses, practices and practitioners in the UK, British Journal of Management, 22(2), 238-253.

Tatli, A., Vassilopoulou, J., Ariss, A. A., \& Özbilgin, M. (2012). The role of regulatory and temporal context in the construction of diversity discourses: the case of the UK, France and Germany, European Journal of Industrial Relations, 18(4), 293-308.

Thomas, D., \& Ely, R. (1996). Making differences matter, Harvard Business Review, 74(5), 79-90.

Thomas, R. (1990). From affirmative action to affirming diversity, Harvard Business Review, 68, $107-117$.

UNESCO Institute for Statistics (2019). http://uis.unesco.org/apps/visualisations/research-and -development-spending/ (retrieved in January 2019). 